\title{
Perceived Tourism Impacts of Tourists on the Environment of the Philippine Military Academy in Baguio City, Philippines
}

\author{
Richard Dein D Altarez ${ }^{1, a^{*}}$, Gabriel Mariko L Lopez ${ }^{2, b}$, \\ Shalimar Elvin M Sawate ${ }^{2, c}$, Jujefell P Bautista ${ }^{2, d}$, Mark C Gayagay ${ }^{2, e}$, \\ Mark Delph Q Lamberte ${ }^{2, f}$, Alberto Lester G Julaquit ${ }^{2, g}$, \\ Ryan Joeferson B De Jesus ${ }^{2, h}$
}

${ }^{1}$ Department of Natural Sciences, Headquarters Academic Group, Philippine Military Academy,
Baguio City, Philippines

${ }^{2}$ Cadet Corps, Armed Forces of the Philippines, Philippine Military Academy, Baguio City, Philippines

ardaltarez@gmail.com, bgabmalopez@gmail.com, 'csemsawate@gmail.com, djujefellpbautista@gmail.com, 'markgayagay@gmail.com, 'fmdlamberte@gmail.com, gjulaquitlester@yahoo.com, hrj_dejesus@gmail.com

Keywords: perception, tourism impacts, tourists, Philippine Military Academy

\begin{abstract}
There has been an incredible increase in tourism activities in the Summer Capital of the Philippines, Baguio City, specifically at the Philippine Military Academy over the years. Unfortunately, these tourism activities led to the growth of a variety of environmental pressures. An environment-friendly or a sustainable form of tourism is seen as a solution to this growing problem. A perception analysis of tourists on the impacts of tourism on the environment of the Philippine Military Academy (PMA) was undertaken. This is a practical approach to gain information about the extent of environmental effects of tourism activity which will also identify areas that can be improved. The study adopted a survey research design with 109 PMA visitors, mainly women $(63.3 \%)$, that are randomly selected. Respondents were surveyed through an online questionnaire from February to April 2019. Results of this study revealed that tourism has a moderate impact on the environment of PMA as perceived by the tourists on the different aspects of tourism including: general management, commercial areas, tourist routes and facilities. It also shows that respondents, regardless of gender, have a considerable level of awareness and concern about the effects of tourism on the PMA environment. Although considered as an environmental disturbance it is also offered that when managed properly, tourism is a positive activity benefiting the host community, environment and all stakeholders alike.
\end{abstract}

\section{Introduction}

The Philippines has many natural and human-made attractions that make tourism one of its major sources of revenue [1-3]. Industry leaders and development experts observed that there had been an apparent growth in tourism in most countries [4]. This has also been factual with the case of Baguio City, the summer capital of the Philippines. Baguio City has long been a place that pulls-in large number of tourists [5]. It is a popular northern Philippine destination for many local and foreign visitors particularly on weekends and holidays, and especially during the Lenten season and the Panagebenga festival [6] Aside from natural attractions such as mountain ranges and bodies of water, Baguio City is also famous as it hosts several historic landmarks and institutions such as The Cathedral, The Mansion, Lourdes Grotto, Bell Church, and the Philippines' premier military school, the Philippine Military Academy (PMA). This military institution boasts a long and illustrious history of preparing the best military officers of the country [7]. It is located at a verdurous pine forest in Fort General Gregorio del Pilar on Loakan road with manicured grounds composed of installed vintage tanks, other historical military weapons [8] and museum, aside from the cadets marching off and performing drills, that entices tourists to see. However, as tourism grows, the 
PMA ground is often overcrowded by individuals and environmental issues, such as garbage problems, wherein plastic bags and containers around are prevalent.

A study by Cassidy et al. [9] shows that the peak of the tourist influx makes the city congested and polluted. According to the Philippine Statistics Authority (PSA), Baguio City has a 345,366 population with a growth rate of 1.54 percent [10]. While tourism is often one of the most efficient and important financial component in developing nations compared to other traditional industries [11-14], it is considered a source of negative reactions including economic such as uneven development, income inequality, geopolitical risks, and social in nature including cultural and heritage problem [12 \& 15].

It is always believed that the growth of tourism industry is tightly linked with environmental degradation such as a decline in the quality of air, water and soil and disturbance or loss of biodiversity affecting negatively tourism itself. A study by Jackson [16], shows the rising indications that the increase of tourism in a natural area is accompanied by a significant increase in environmental effects such as excessive emission of greenhouse gases, scarcity of water and other resources and excess consumption of energy. Although, tourism can be a significant tool for economic development, it also poses destructive impacts on biodiversity and pristine environments if not adequately planned. It can result in misuse of natural resources such as freshwater, forests and marine life if improperly managed [17-20]. To avoid these negative consequences, tourism should be managed and planned in a way that it must not compromise the environment and the socioeconomic viability [21].

Planning and management of a tourism destination can significantly decrease the general impact of facets of tourism [22]. This can be achieved through the participation and support of the tourists [23]. Determining the views of tourists on the impacts of tourism can provide valuable information not only about the existence but also on the extent of environmental effects of tourism activities [24]. When problems and gaps in management process is carefully determined and taken into account seriously, it will lead to creating a more sound policy intervention for the proper management of tourism site $[18,19]$ which will benefit the host institution, the environment and the tourists as well $[25,26]$. In the Philippine Military Academy, it is unclear whether tourists also recognize their impacts on its environment. No such studies have been conducted focusing on the PMA grounds or in other military installations in the Philippines [27]. This needs to be measured in order to come up with appropriate management policies and plan for the sustainability of the academy's tourism and environment. Hence, a study which aims to determine the perception of visitors regarding the impacts of tourism on the environment of the PMA is conducted.

\section{Materials and Methods}

The primary research method that was used in this study is quantitative design in the form of a survey. The survey conducted in this research is descriptive. The descriptive purpose of this study is to look at the perception of the visitors on the impacts of tourism on the environment of PMA. The instrument used to collect data in this survey is by using an internet-based questionnaire. The questionnaire consists of questions that are adopted from the study of du Plesis [25] on the general management, commercial area, tourist routes, and tourist facilities. A four (4) point Likert scale was developed to investigate the perception of the respondents, and the mean was used to analyze and interpret the data using the table below (Table 1). 
Table 1. Likert scale for the perceived tourism impacts of tourists on the environment of PMA

\begin{tabular}{cccc}
\hline Scale & $\begin{array}{c}\text { Scale } \\
\text { Limits }\end{array}$ & Level & Interpretation \\
\hline 4 & $3.25-4.00$ & Major & This tourism aspect has a major impact on the environment of \\
PMA
\end{tabular}

The data collection was carried out from February to April 2019. The researchers distributed the questionnaire link through email and social media and gave some time for the respondents between the ages of 15 and 70 years old to fill in their answers and to avoid incomplete entries. The questionnaire was pre-tested to ten (10) respondents for clarity and reliability of questions. Each questionnaire items were also tested for reliability through Cronbach's Alpha Coefficient measurement. The population of tourists in PMA per month is roughly around 5,000. The computed sample size for the said population with $\pm 10 \%$ margin of error and a $95 \%$ confidence level or a $\mathrm{z}$ score of 1.96, with an assumed population proportion of 0.5 , is 94 . Sample population for the respondents was calculated using the following Chochran's formula [ 28 \& 29] where, $\mathrm{z}$ is the $\mathrm{z}$ score, $\varepsilon$ is the margin of error, $n$ is population size, and $\hat{p}$ is the population proportion:

$$
n=\frac{\mathrm{z}^{2} \times \hat{\mathrm{p}}(1-\hat{\mathrm{p}})}{\varepsilon^{2}} \quad \div \quad \frac{\mathrm{z}^{2} \times \hat{\mathrm{p}}(1-\hat{\mathrm{p}})}{\varepsilon^{2} \mathrm{~N}}
$$

The questionnaires were randomly sent to 110 respondents that are at least a graduate of secondary school and able to visit PMA. 109 respondents were able to accomplish the questionnaire.

\section{Study site}

The research was carried out in the Philippine Military Academy, Loakan Road, Baguio City, Philippines at Fort Gregorio del Pilar (Figure 1). It is approximately $250 \mathrm{~km}$ north of Manila and roughly 1,400 $\mathrm{m}$ above sea level nestled within the Cordillera Central mountain range with an average temperature of $20^{\circ} \mathrm{C}$. The main motivators for tourists to visit an area are attractions, these play an important part in a destination's success [30]. In PMA, tourists visit ancient historical landmarks such as the old Melchor Hall Building. Other attractions include the relics point where military tanks and weapons are located, amphitheater, museum, sundial area where old air crafts are also located (Figure 2). Business establishments, parking spaces and comfort rooms are also present to serve the tourist [31].

\section{Results and Discussion}

The reliability of each item in the survey questionnaire was measured using the Cronbach's Alpha Coefficient. Table 2 shows the result of the reliability test for the four variables. It is recommended that Chronbach's alpha values above 0.7 as a sufficient measure of reliability or internal consistency of an instrument [32]. The table below shows that the variables addressed in the questionnaire achieved a reliability of 0.8 and above, reflecting the items in the questionnaire reliable and deletion is not required. 
Table 2. Reliability coefficients for the variables

\begin{tabular}{ccc}
\hline Variable & No. of item & Cronbach's Alpha \\
\hline General management tourism aspect & 10 & 0.917 \\
Commercial area tourism aspect & 5 & 0.851 \\
Tourism Routes tourism aspect & 12 & 0.962 \\
Tourist facilities tourism aspect & 9 & 0.948 \\
\hline
\end{tabular}

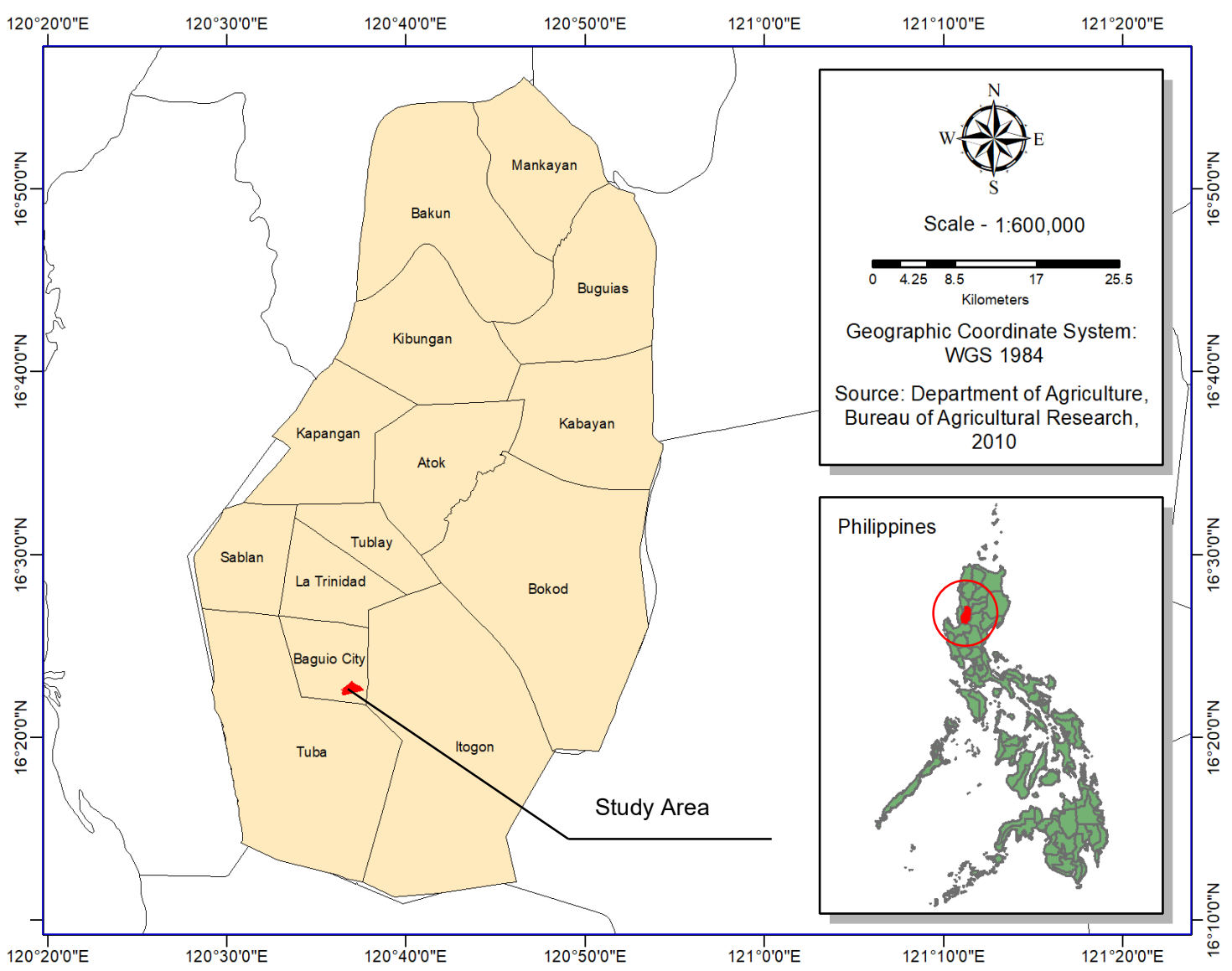

Figure 1. Location map of the study area 


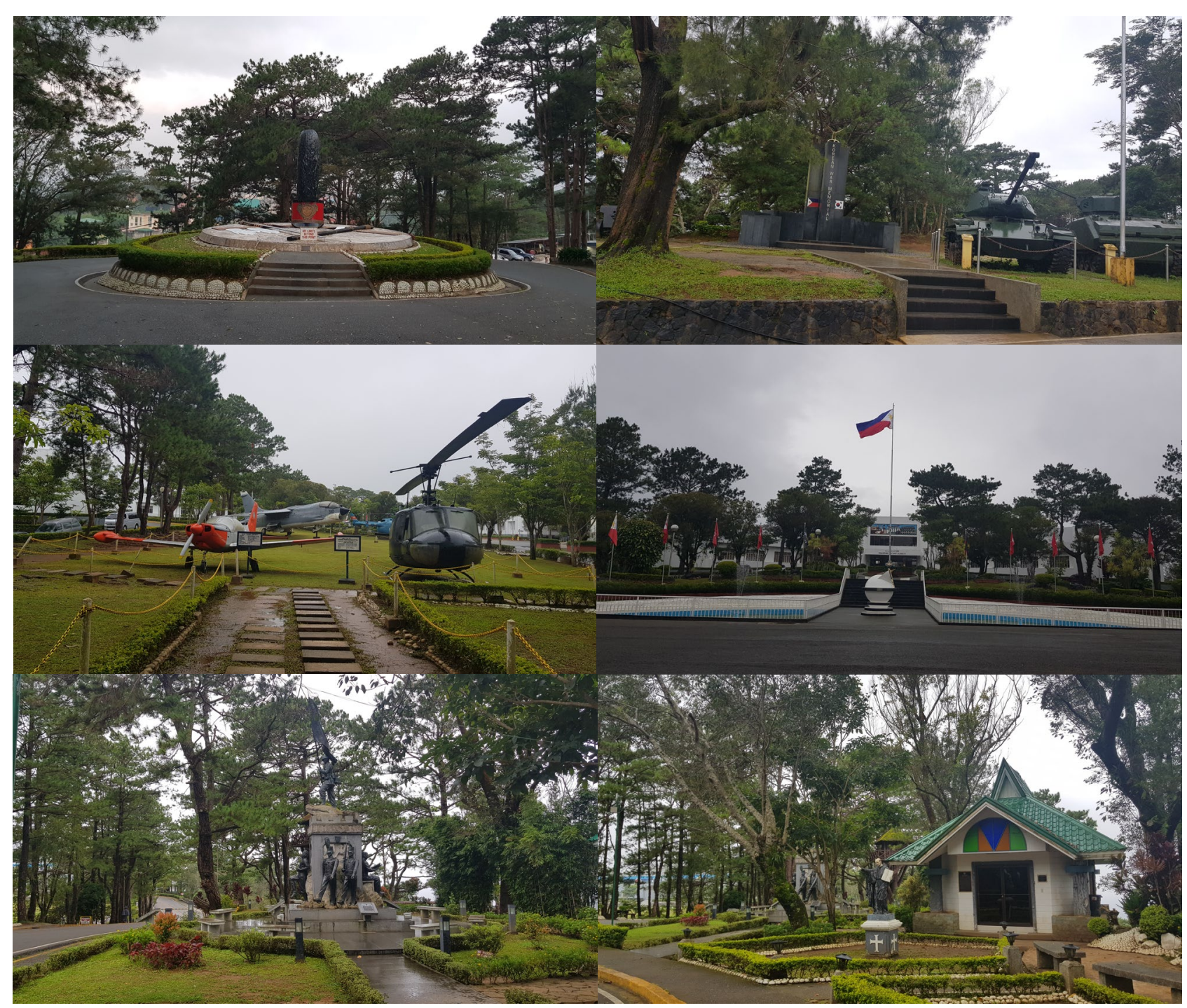

Figure 2. Some of the tourist destinations inside the Philippine Military Academy: A. The shako monument; B. Relics point; C. Military aircrafts; D. Sundial area; E. The PMAyer monument;

\section{F. Prayer room}

The study set out to investigate the perceived tourism impact of tourists on the environment of PMA. The respondents of this study were predominantly females (63.3\%). Most of the respondents were between 18 to 27 years old. $86.2 \%$ are single, and $13.8 \%$ were married. Respondents are well educated since $33.9 \%$ of them were college graduate, $56 \%$ were in the tertiary level, and the rest were in the secondary level of education.

The respondents believed that general management in the PMA has a moderate impact on its environment (Table 3). This shows that pollution (solid waste, noise and aesthetic), lack of energy and water saving measures, inappropriate solid waste management and sewage discharge, excessive tourists in the area, no environment-friendly products, and limited Information Education Campaign (IEC) materials are all present in the PMA. This gives the impression that these aspects contribute to the negative consequence of tourism on the place. Inappropriate water pollution discharge, for instance, can carry potential diseases which can be spread out by vermin such as flies, mouse, and cockroach affecting human health. Noise pollution, such as those coming from the vehicles, causing annoyance and distress not only to humans but to wildlife as well. Improper disposal of solid wastes adds on the poor aesthetic condition of the area, and it also attracts unwanted pests. The presence of too many visitors also entails problems on the environment. Tourist activities can alter the integrity of cultural resources. This damage includes vandalism and looting of sites of cultural significance [18]. Likewise, the vehicles of the tourists that pile up in one parking area congest that zone and emit a large amount of carbon dioxide. Also, the absence of environment-friendly products such as 
paper bags adds on the long-time garbage problem is observed. Finally, the lack of IEC reduces the awareness of people on the possible impacts they might bring in the environment of PMA. IEC materials such as brochures and information booklets provide information on the potential harm a human can do whenever they go closer with nature and the environment. It also includes information about how people can mitigate their impacts on nature.

Table 4 shows that respondents perceived commercial area tourism aspect has moderate impact on the environment of PMA. The respondents see that inappropriate waste disposal and not making use of locally produced products of restaurants, utilization of single use plastics, visible pollution at restaurants and non-organic food products exist in PMA, and all these attributes have a negative impact contribution in the environment of PMA. The plastic bags for instance, has seen to create environmental challenges because of its physical and chemical composition [33-35]. Plastics are made of fossil fuels that are infamous for its contribution on the worsening effects of the global climate change.

Table 3. Perception of tourists on the impacts of the general management tourism aspects on the environment of PMA

\begin{tabular}{|c|c|c|}
\hline General Management Tourism Aspect & Mean & Level \\
\hline 1. Solid waste/Litter/Garbage & 3.11 & Moderate \\
\hline $\begin{array}{l}\text { 2. Lack of energy saving measures (for ex. Energy saving lights, solar } \\
\text { panels, etc.) }\end{array}$ & 2.83 & Moderate \\
\hline 3. Inadequate water saving measures & 2.98 & Moderate \\
\hline 4. Visual Pollution (For ex: signs/advertising, building structures) & 2.94 & Moderate \\
\hline 5. Noise Pollution (For ex: Music/people) & 2.75 & Moderate \\
\hline 6. Sewerage Systems (Inappropriate discharge) & 2.99 & Moderate \\
\hline $\begin{array}{l}\text { 7. Inappropriate waste management - the absence of recycling waste } \\
\text { bins }\end{array}$ & 3.01 & Moderate \\
\hline 8. Too many tourists in the park at a given time & 3.02 & Moderate \\
\hline $\begin{array}{l}\text { 9. Lack in the use of environmentally friendly products (For ex: } \\
\text { Paper bags) }\end{array}$ & 2.66 & Moderate \\
\hline $\begin{array}{l}\text { 10. Lack of brochures and information booklets about the tourism } \\
\text { site. }\end{array}$ & 2.78 & Moderate \\
\hline Mean & 2.90 & Moderate \\
\hline
\end{tabular}

Table 4. Perception of tourists on the impacts of commercial area tourism aspects on the environment of PMA

\begin{tabular}{lcc}
\hline \multicolumn{1}{c}{ Commercial Areas Tourism Aspect } & Mean & Level \\
\hline 1. Inappropriate waste disposal at restaurants (For ex: not using & 2.96 & Moderate \\
organic gardens) & 2.63 & Moderate \\
2. Restaurants not making use of locally produced products & 3.09 & Moderate \\
3. Impacts of using non-renewable resources (For ex: plastics) & 2.91 & Moderate \\
4. Pollution at restaurants & 2.58 & Moderate \\
5. Use of food products that aren't organic & $\mathbf{2 . 8 9}$ & Moderate \\
\hline Mean
\end{tabular}

The tourist routes tourism aspects have moderate impact on the environment of PMA according to the respondents (Table 5). Attributes under these aspects include the physical damage on the natural vegetation and soil, impacts on wildlife and plants, and speeding vehicles that may kill animals. The aforesaid activity disturbs wildlife in many ways. Many species will perceive the consequent disturbance in various ways and for different reasons. Some will be affected in terms of their breeding season, feeding patterns, behaviors, and many more [20]. Visitors may damage the ecosystem due to their activities such as walking. along restricted areas or places where trails are not apparent resulting to trampled vegetation. One or two tourists may not cause visible harm, but 
hundreds over time can do substantial damage [20] One notable attribute under this aspect is the possible introduction of alien species. Many visitors do not know the effects of introducing alien/exotic species in an environment. This species threatens the local environment and interferes with the essential species balance, and generally destabilizes the ecosystem.

The respondents perceived tourist facilities tourism aspects have a moderate impact on the environment of PMA (Table 6). Under these are waste spillage in the garbage bins, interference of animals, wildlife attracted to rubbish bins, lack of energy saving measures, lack of waste management and use of non-renewable resources by tourist. Each of these aspects have detrimental effects on the environment. The solid waste management has been a long-time problem all throughout the Philippines. Despite the passing of the RA9003 or the Ecological Solid Waste Management Act of 2001, many organizations and institutions fail to comply properly on the provision of the said law.

Table 5. Perception of tourists on the impacts of tourist routes tourism aspects on the environment of PMA

\begin{tabular}{lcc}
\hline \multicolumn{1}{c}{ Tourist Routes Tourism Aspect } & Mean & Level \\
\hline 1. Damage to natural vegetation due to uncontrolled tourist behavior & 3.15 & Moderate \\
2. Erosion in the roadway due to tourists & 2.96 & Moderate \\
3. Overcrowding of tourist at wildlife sightings & 2.91 & Moderate \\
4. Impacts of wildlife attracted to rubbish bins along tourist routes & 2.87 & Moderate \\
5. Impacts of plant collecting along tourist routes & 2.84 & Moderate \\
6. Introduction of alien plants and species due to tourism & 2.63 & Moderate \\
7. Interference of breeding of wildlife due to tourism & 2.70 & Moderate \\
8. Specimen collection (for ex: butterflies) by tourists & 2.75 & Moderate \\
9. The killing of animals for comfort and safety (for ex: spiders, & 2.78 & Moderate \\
snakes, mosquitos) & & \\
10. Road killings as a result of reckless tourist driving and speeding & & \\
in the tourism site. & 2.91 & Moderate \\
11. Speeding of staff and delivery vehicles in the site & 2.81 & Moderate \\
12. Lack of environmental-friendly support & 2.88 & Moderate \\
\hline Mean & $\mathbf{2 . 8 4}$ & Moderate \\
\hline
\end{tabular}

Table 6. Perception of tourists on the impacts of tourist facilities tourism aspects on the environment of PMA

\begin{tabular}{lcc}
\hline Tourist Facilities Toursim Aspect & Mean & Level \\
\hline 1. Waste spillage around waste bins by tourists & 3.09 & Moderate \\
2. Interference of wildlife due to noise, cars, and people & 2.93 & Moderate \\
3. Overcrowding of people & 3.17 & Moderate \\
4. Visual pollution (e.g. signs and direction) & 2.99 & Moderate \\
5. Wildlife attracted to rubbish bins & 2.91 & Moderate \\
6. Supplementary feeding of wildlife by tourists & 2.72 & Moderate \\
7. Lack of energy-saving measures (e.g. solar panels) & 2.72 & Moderate \\
8. Insufficient management of waste (e.g. lack of recycling measures) & 3.08 & Moderate \\
9. Use of non-renewable resources (e.g. plastic) by tourist & 3.09 & Moderate \\
\hline Mean & $\mathbf{2 . 9 6}$ & Moderate \\
\hline
\end{tabular}

The respondents believed that the impact of tourism aspects in the environment of PMA was all moderate. It means that the management of the PMA has still a lot to improve in order to lower the tourists' perceived tourism impacts in the environment of the academy. More so, each aspect presented above can be used as indicator on which areas to improve. Study shows that the PMA can improve further on the aspects of general management, commercial areas, tourist routes and tourist facilities. A sustainable tourism management approach can be carried out as an improvement for the 
tourism in PMA. Moreover, an independent sample t-Test was performed to determine the significant difference of perception between female and male respondents (Table 7). The analysis revealed that there is no significant difference in the perception of female and male respondents ( $\mathrm{t}$ stat $=5.49>\mathrm{t}$ Critical two-tail; and $\mathrm{P}$ value $\left.=5.84 \times 10^{-7}<\mathrm{a}=0.05\right)$.

Table 7. Independent sample t-Test for female and male respondents mean responses

\begin{tabular}{cccccc}
\hline Variable & Mean & StDev & t stat & T Critical two-tail & P value \\
\hline Female & 2.97 & 0.03 & 5.49 & \multirow{2}{*}{1.99} & $5.84 \times 10^{-7}$ \\
Male & 2.76 & 0.03 & & & \\
\hline
\end{tabular}

\section{Conclusions and Recommendations}

The study revealed the impacts of tourism on the environment of PMA, pointing out different problems, challenges, and negative consequences to the environment of the various aspects of tourism in the Academy. The tourists believe that the general management, commercial areas, tourist routes and facilities at PMA have moderate impact on its environment. This agrees to other studies that tourists perceive tourism negatively affects the overall make-up of an environment [36, 37]. Moreover, tourists, irrespective of gender, have considerable level of awareness and concern on the impacts of tourism in an environment of a destination site [38-40]. Findings of this study gives out valuable insights on how the academy can improve its tourism management to make it more environmentally friendly and sustainable. A policy that details the management plan on tourism in the PMA considering the results of this study is suggested. This will offer the Academy officials and managers a clear perspective of what needs to be taken into account when designing a sustainable tourism in PMA. For a more complete understanding on the impacts of tourism on the PMA, a similar study targeting other stakeholders such as personnel, students and residents is greatly recommended wherein the results shall be compared and integrated with the results of this study.

\section{Acknowledgements}

The authors wish to thank the Philippine Military Academy, 1CL JOSEFINA C BACALSO CCAFP for making the online questionnaire, and Ms Ma. Glovedi Joy L. Bigornia and Angelo R. Agduma for improving the content of this article.

\section{Conflict of Interest}

The authors declare that they have no affiliations with or involvement in any organization or entity having any financial or non-financial interest in the topic or materials discussed in this manuscript.

\section{References}

[1] W. Manueala, M. de Vera, The impact of government failure on tourism in the Philippines, Transport Policy. 43 (2015) 11-22.

[2] JJP. Manalo, Developmeny through sustainable tourism and effective policy implementation: Practices of Puerto Princesa City, Philippines, Asia Pacific Journal of Multidisciplinary Research. 59 (1) (2017)

[3] R. Aquino, H. Achanzel, K. Hyde, 2018. Unearthing the geotourism experience: Geotourist perspectives at Mount Pinatubo, Philippines, Tourist Studies. 18(1) (2018) 41-62.

[4] C. Ashley, P. De Brine, A.Lehr, H. Wilde, The role of the tourism sector in expanding economic opportunity: Corporate social responsibility initiative report no. 23. Cambridge, MA: Kennedy School of Government, Harvard University, 2007. 
[5] I. Morley, Baguio: A mismanaged evolutionary narrative of the city beautiful to the city problematic, Asian Geographer. 35 (2) (2018) 1-19

[6] H. Hagad, M. Cayetano, $\mathrm{PM}_{10}$ and surface duct source characterization in Baguio City Central Business District (CBD), Philippines. Environ Geochem Health. 41(1) (2019) 427-446

[7] G. Nerona, J. Park, K. Bogbog, M. Tamondong, Improving the food storage and inventory management of a military cadet institution: Boosting students' problem-solving skills through collaborative applied research, Global Journal of Engineering Education. 20 (3) (2018) 201206

[8] E. Stach, A. Pawlowska, L. Matoga, The development of tourism at military-historical structures and sites - a case study of the building complexes of project riese in the owl mountains, Pol.J.Sport Tourism. 21 (2014).

[9] B.E. Cassidy, M.A. Alabanza-Akers, T.A. Akers, D.B. Hall, P.B. Ryan, C.W. Bayer, L.P. Naeher, Particulate matter and carbon monoxide multiple regression models using environmental characteristics in a high diesel-use area of Baguio City, Philippines, Science of the Total Environment. 381 (2007) 47-58.

[10] Philippine Statistics Authority, Population of the Cordillera Administrative Region (based on the 2015 census of population) [Online]. Available: https://psa.gov.ph/population-andhousing/title/Population_of_the_Cordillera_Administrative_Region_(Based_on_the_2015_Ce nsus_of_Population)

[11] S.E. Meimand, Z. Khalifah, E.K. Zavadskas, A. Mardani, A.A. Najafipour, U.N.U. Ahmad, Residents' attitude toward tourism development: A sociocultural perspective. Sustainability. 9 (7) (2017).

[12] M. Azam, M. Mahmudul Alam, M. Haroon Hafeez, Effect of tourism on environmental pollution: Further evidence from Malaysia, Singapore and Thailand, Journal of Cleaner Production. 190 (2018) 330-338.

[13] T.H. Lee, F. Jan, Can community-based topurism contribute to sustainable development? Evidence from residents' perceptions of the sustainability, Tourism Management. 70 (2019) 368-380.

[14] D. Gursoy, Z. Ouyang, R. Nunkoo, W. Wei, Residents' impact perceptions of and attitudes towards tourism development: a meta-analysis. Journal of Hospitality Marketing and Management. 28 (3) (2019) 306-333.

[15] J.K.S. Jacobsen, N.M. Iversen, L.E. Hem, Hotspot crowding and over-tourism: Antecedents of destination attractiveness, Annals of Tourism Research. 76 (2019) 53-66.

[16] S. Jackson, Attitudes towards the environment and ecotourism of stakeholders in the UK tourism industry with particular reference to ornithological tour operators, Journal of ecotourism. 6 (1) (2007) 34-66.

[17] I. Kavallinis, A. Pizam, 1994. The environmental impact of tourism-whose responsibility is in anyway?the case study of Mykonos, Journal of Travel Research. 33 (2) (1994) 26-32.

[18] Md. Ghulam Rabbany, S. Afrin, A. Rahman, F. Islam, F. Hoque, Environmental effects of tourism, American Journal of Environment, Energy and Power Research. 1(7)(2013)117-130.

[19] F. Garcia, A. Vazquez, R. Macias, Resident's attitude towards the impacts of tourism. Tourism Management Perspectives. 13 (2015) 33-40.

[20] A.M.B. Selamat, M. Chelamuthu, K. Abdullah, B. Mohamed, A study of visitor's perception on the impacts of tourism activities, development and infrastructure on the environment of redang island, Journal of Modern Education Review. 6 (9) (2016) 648-654. 
[21] J.J.P. Manalo, Development through sustainable tourism and effective policy implementation: Practices of Puerto Princesa City, Philippines, Asia Pacific Journal of Multidisciplinary Research. 5 (1) (2017).

[22] P.C. Morales, F.O. Auera, T. Lopez-Guzman, S.M. Cuadre, Community attachment and support for sustainable tourism development through the attitudes of the local population: A case study in Puerto Plata, Dominican Republic, Mediterranean Journal of Social Sciences. 9 (2) (2018) 173-184.

[23] P.M. Huong, J. Lee, Finding important factors affecting local residents' support for tourism development in Ba Be National Park, Vietnam, Forest Science and Technology. 3 (3) (2017)

[24] N. Aspe, M. Mabuhay-Omar, N. Nakagoshi, Perception of citizens toward implementation of urban forestry: case of local city in the Philippines, Landscape Ecology for Sustainable Society. (2017) 295-308

[25] L. du Plessis, Tourists' perceptions of tourism impacts on the environment: The case of South African National Parks. MS Thesis. Potchesfstroom Campus North-West University, 2010.

[26] S.L. Snyman, The role of tourism employment in poverty reduction and community perceptions of conservation and tourism in southern Africa, Journal of Sustainable Tourism. 20(3) (2012) 395-416.

[27] A. Weaver, Tourism and the military: pleasure and the war economy, Annals of Tourism Research. 38 (2) (2011) 672-689.

[28] G.D. Israel, Determining sample size. [Online] Available: https://edis.ifas.ufl.edu/

[29] H.K. Sarmah, B. Hazarika, G. Choudhury, An investigation on effect of bias on determination of sample size on the basis of data related to the students of schools of Guwahati, International Journal of Applied Mathematics \& Statistical Sciences. 2 (1) (2013) 33-48.

[30] L. De Witt, P. van der Merwe, P. 2013. An ecotourism model for South African National Parks, Southern African Institute for Management Scientists Conference - 2013. 46 (2013) 877-894.

[31] Philippine Military Academy, The Philippine Military Academy [Online]. Available: https://www.pma.ph/about.php.

[32] K. Taber, The use of cronbach's alpha when developing and reporting research instruments in science education, Research in Science Education. 48 (6) (2018) 1273-1296.

[33] P. Chen, The need for reducing plastic shopping bag use and disposal in Africa, African Journal of Environmental Science and Technology. 3 (3) (20018).

[34] J. Clapp, L. Swanston, Doing away with plastic shopping bags: international patterns of norm emergence and policy implementation, Environmental Politics. 18 (3) (2009) 315-332.

[35] T.D. Nielsen, K. Holmberg, J. Stripple, J. Need a bag? A review of public policies on plastic carrier bags - where, how and to what effect?, Waste Management. 87 (2019) 428-440.

[36] S. Eslami, Z. Khalifah, A. Mardani, D. Streimikiene, Impact of non-economic factors on residents' support for sustainable tourism development in Langkawi Island, Malaysia, Economics and Sociology. 11 (4) (2018).

[37] A. Sangpikul, Tourist perceptions of guided ecotourism tours in Thailand. Tourism and hospitality research. 0 (0) (2019) 1-12. 
[38] V.M. Gonzales, L. Coromina, N. Gali, Overtourism: residents' perceptions of tourism impacts as an indicator of resident social carrying capacity - case study of a Spanish heritage town, Tourism review. 73 (3) (2018).

[39] X. He, D. Hu, S.R. Swanson, L. Su, X. Chen, X. Destination perceptions, relationship quality and tourist environmentally responsible behaviour, Tourism Management Perspectives. 28 (2018) 93-104.

[40] D. Joo, H. Cho, K.M. Woosnam, Exploring tourists' perceptions of tourism impacts, Tourism Management Perspectives. 31 (2019) 231-235. 